\title{
PENYAKIT AKIBAT KERJA DI RUMAH SAKIT KEPADA PERAWAT
}

\author{
Niken Malinda Putri \\ nikenmalindaputri01@gmail.com
}

Latar Belakang

Keselamatan dan kesehatan kerja merupakan hal penting yang harus diterapkan di semua tempat kerja, baik pada sektor formal maupun sektor informal. Terlebih bagi tempat kerja yang memiliki risiko atau bahaya yang tinggi, serta dapat menimbulkan kecelakaan kerja maupun penyakit akibat kerja. keselamatan dan kesehatan kerja seharusnya diterapkan pada semua pihak yang terlibat dalam proses kerja, mulai dari tingkat manager sampai dengan karyawan biasa. Berdasarkan Undang-Undang No. 1 Tahun 1970 yang menyatakan bahwa setiap tenaga kerja memiliki hak untuk mendapat perlindungan bagi keselamatannya dalam melakukan pekerjaan untuk kesejahteraan hidup dan meningkatkan produksi serta produktivitas Nasional.

Berdasarkan undang-undang No. 44 Tahun 2009 tentang rumah sakit, menyatakan rumah sakit adalah institusi pelayanan kesehatan yang menyelenggarakan pelayanan kesehatan perorangan secara paripurna yang menyediakan pelayanan rawat inap, rawat jalan, dan gawat darurat. Karena merupakan suatu institusi yang bergerak dalam bidang pelayanan kesehatan, maka rumah sakit juga termasuk dalam kategori tempat kerja. Isi dalam pasal 23 undang-undang No. 23 Tahun 1992 tentang kesehatan menyatakan bahwa setiap tempat kerja wajib menyelenggarakan kesehatan kerja. Berdasarkan pernyataan tersebut, maka rumah sakit sebagai salah satu tempat kerja juga wajib untuk menyelenggarakan kesehatan kerja bagi para pekerjanya agar terhindar dari potensi bahaya yang ada di rumah sakit.

Frekuensi kecelakaan kerja di perusahaan semakin meningkat, sementara kesadaran pengusaha terhadap Kesehatan dan Keselamatan Kerja (K3) masih rendah, yang lebih memprihatinkan pengusaha dan pekerja sektor kecil menengah menilai K3 identik dengan biaya sehingga menjadi beban, bukan kebutuhan. Catatan PT Jamsostek dalam tiga tahun terakhir (1999 - 2001) terbukti jumlah kasus kecelakaan kerja mengalami peningkatan, dari 82.456 kasus pada 1999 bertambah menjadi 98.902 kasus di tahun 2000 dan berkembang menjadi 104.774 kasus pada 2001. Untuk angka 2002 hingga Juni, tercatat 57.972 kasus, sehingga rata - rata setiap hari kerja terjadi sedikitnya lebih dari 414 kasus kecelakaan kerja di perusahaan yang tercatat sebagai anggota Jamsostek. Sedikitnya 9,5 persen dari kasus kecelakaan kerja mengalami cacat, yakni 5.476 orang tenaga kerja, sehingga hampir setiap hari kerja lebih dari 39 orang tenaga kerja mengalami cacat tubuh (PPNI, 2010). 
Menurut pusat data dan informasi Kementerian Kesehatan RI (2015) tentang situasi kesehatan kerja tahun 2015, Jumlah kasus kecelakaan akibat kerja yang terjadi antara tahun 2011-2014 adalah sebesar 92.453 kasus dengan jumlah kasus paling tinggi terjadi pada tahun 2013 yaitu sebesar 35.917 kasus. Sedangkan data untuk kasus penyakit yang terjadi akibat kerja antara tahun 2011-2014 adalah 57.929 kasus tahun 2011, 60.322 kasus tahun 2012, 97.144 kasus tahun 2013, dan 40.694 kasus pada tahun 2014. Dari data-data tersebut, dapat disimpulkan bahwa situasi kesehatan kerja di Indonesia masih belum baik.

Salah satu tempat kerja yang berisiko adalah Rumah Sakit, hal ini karena rumah sakit memiliki potensi terjadinya penyakit infeksi terhadap para karyawan, pasien, bahkan pengunjung. Beberapa contoh penyakit infeksi yang dapat terjadi di Rumah Sakit adalah TB, Hepatitis B, Hepatitis C, dan bahkan berisiko terinfeksi HIV/AIDS. Selain penyakit-penyakit infeksi, di rumah sakit juga memiliki risiko atau bahaya lain yang mempengaruhi situasi dan kondisi di rumah sakit, seperti kecelakaan (meliputi kejadian ledakan, kebakaran, kecelakaan yang diakibatkan adanya masalah pada instalasi listrik, serta faktor-faktor yang dapat menimbulkan cidera lainnya), radiasi, paparan bahan kimia beracun dan berbahaya, gasgas anastesi, gangguan terkait psikis dan ergonomi. Semua potensi bahaya tersebut di atas, jelas dapat mengganggu dan menimbulkan rasa kurang aman dan nyaman bagi pekerja di RS, pasien maupun pengunjung yang ada di lingkungan RS. (KEPMENKES N0.432 Tahun 2007).

\section{Metode}

Metode yang saya gunakan dalam membuat kajian ini adalah metode literasi. Saya membaca berbagai literature maupun referensi dari jurnal, buku, koran, majalah maupun buku elektronik. Dengan metode literature ini saya dapat mengetahui apa saja faktor-faktor yang menyebabkan penyakit akibat kerja (PAK) dan kecelakaan akibat kerja (KAK) yang terjadi pada perawat di rumah sakit. Selain itu saya juga dapat mengetahui penyakit apa saja yang dapat ditimbulkan dari PAK dan KAK.

\section{Hasil}

Dari literature yang saya baca saya dapat mengetahui bahwa setiap tenaga kerja memiliki hak untuk mendapat perlindungan bagi keselamatannya dalam melakukan pekerjaan untuk kesejahteraan hidup dan meningkatkan produksi serta produktivitas Nasional.

Saya juga mengetahui bahwa tempat yang paling berisiko adalah rumah sakit. Disana perawat juga mempunyai risiko tinggi terjadinya penyakit akibat kerja (PAK) karena perawat 
merupakan pelayanan keperawatan yang dimana paling sering melakukan kontak dengan pasien yang dapat menularkan penyakit.

Selain penyakit-penyakit infeksi risiko dapat juga ditimbulkan dari faktor lingkungan kerja. seperti kecelakaan (meliputi kejadian ledakan, kebakaran, kecelakaan yang diakibatkan adanya masalah pada instalasi listrik, serta faktor-faktor yang dapat menimbulkan cidera lainnya), radiasi, paparan bahan kimia beracun dan berbahaya, gasgas anastesi, gangguan terkait psikis dan ergonomi. Semua

K3 sangat penting dan harus diperhatikan oleh pekerja dan hal ini menjadi tanggung jawab bersama, perlu adanya kerja sama antara pemerintah, perusahaan dan pekerja agar terhindar dari Kecelakaan Akibat Kerja (KAK) dan Penyakit Akibat Kerja (PAK).

Sebagai perawat selain memberi asuhan keperawatan perawat juga harus sadar akan perannya sebagai kunci dalam penerapan K3 yang dimana untuk menghindari penyakit akibat kerja (PAK) dan kecelakaan akibat kerja (KAK). Sebagai faktor penyebab, sering terjadi karena kurangnya kesadaran pekerja dan kualitas serta keterampilan pekerja yang kurang memadai.

Untuk memenuhi hal tersebut perawat juga haruslah mempunyai pengetahuan tentang k3, PAK, KAK dan risiko yang dihadapinya. Karena itu perawat harus menjadi perawat professional yang mampu dan mempunyai pengetahuan dan kreativitas.

Dengan tercapainya hal ini dapat meningkatkan efesiensi kesehatan serta rumah sakit.

Karena Kecelakaan kerja pada perawat dianggap sebagai suatu masalah serius karena mengancam kesehatan dan kesejahteraan pasien dan petugas kesehatan secara global Kecelakaan tersebut yang pada akhirnya dapat mempengaruhi produktivitas kerja perawat. Produktivitas kerja yang rendah pada akhirnya berdampak terhadap pelayanan kesehatan yang diberikan oleh rumah sakit.

\section{Pembahasan}

Kesehatan kerja merupakan suatu unsur kesehatan yang berkaitan dengan lingkungan kerja dan pekerjaan, yang secara langsung maupun tidak langsung dapat mempengaruhi efisiensi dan produktivitas kerja. Sedangkan, keselamatan kerja merupakan suatu sarana utama untuk mencegah terjadinya kecelakaan kerja yang dapat menimbulkan kerugian berupa luka atau cidera, cacat atau kematian, kerugianharta benda, kerusakan peralatan atau mesin dan kerusakan lingkungan secara luas. 
Kecelakaan adalah kejadian tidak terduga yang disebabkan oleh tindakan tidak aman dan kondisi tidak aman (Heinrich, 1930). Sebagian besar (85\%) kecelakaan disebabkan oleh faktor manusia dengan tindakan yang tidak aman. Tindakan tidak aman (unsafe action) adalah tindakan yang dapat membahayakan pekerja itu sendiri maupun orang lain yang dapat menyebabkan terjadinya kecelakaan yang dapat disebabkan oleh berbagai hal seperti tidak memakai APD, tidak mengikuti prosedur kerja, tidak mengikuti peraturan keselamatan kerja dan bekerja tidak hati-hati, dimana dari setiap 300 tindakan tidak aman, akan terjadi 1 (satu) kali kecelakaan yang mengakibatkan kehilangan hari kerja.

Ancaman kecelakaan kerja di tempat kerja di negara berkembang seperti Indonesia masih sangat tinggi. Hasil laporan National Safety Council tahun 1988 menunjukkan bahwa terjadinya kecelakaan kerja di rumah sakit $41 \%$ lebih besar dari pekerja industri lainnya. Kasus yang sering terjadi adalah tertusuk jarum, terkilir, sakit pinggang, tergores, luka bakar dan penyakit infeksi lainnya. Laporan lainnya di Israel angka prevalensi cedera punggung tertinggi pada perawat $(16,8 \%)$ dibandingkan pekerja industri lainnya. Di Australia, diantara 813 perawat, $87 \%$ pernah mengalami low back pain (Sholihah, 2013).

Pada hakekatnya Keselamatan dan Kesehatan Kerja (K3) merupakan suatu usaha untuk menciptakan perlindungan dan keamanan dari berbagai risiko kecelakaan dan bahaya, baik fisik, mental maupun emosional terhadap pekerja, perusahaan, masyarakat dan lingkungan. Disamping itu, keselamatan dan kesehatan kerja diharapkan dapat menciptakan kenyamanan kerja dan keselamatan kerja yang tinggi.

Berdasarkan peraturan pemerintah Republik Indonesia No. 50 Tahun 2012 tentang penerapan sistem manajemen keselamatan dan kesehatan kerja (SMK3) pada lampiran 1 pedoman penerapan SMK3 wajib melaksanakan perencanaan K3 yang didalamnya berisi identifikasi potensi bahaya, penilaian dan pengendalian risiko. Identifikasi Bahaya (Hazards Identification), Penilaian Risiko (Risk Assessment) dan Pengendalian Risiko (Risk Control) atau yang disingkat HIRARC merupakan suatu elemen pokok dalam sistem manajemen Keselamatan dan Kesehatan Kerja yang berkaitan dengan upaya pencegahan dan pengendalian bahaya. Keseluruhan proses dari HIRARC yang disebut juga dengan manajemen risiko (risk management), kemudian akan menghasilkan dokumen HIRARC yang sangat berguna untuk mencegah terjadinya kecelakaan kerja.

Berdasarkan data International Labour Organization (ILO) tahun 2013, satu pekerja di dunia meninggal setiap 15 detik karena kecelakaan kerja dan 160 pekerja didunia mengalami penyakit akibat kerja (PAK). Diperkirakan 2,3 juta pekerja meninggal setiap tahun akibat 
kecelakaan dan penyakit akibat kerja (PAK). Lebih dari 160 juta pekerja menderita penyakit akibat kerja dan 313 juta pekerja mengalami kecelakaan tidak fatal per tahunnya.

Menurut Undang-undang No. 44 Tahun 2009 Rumah Sakit adalah institusi pelayanan kesehatan bagi masyarakat dengan karakteristik tersendiri yang dipengaruhi oleh perkembangan ilmu pengetahuan kesehatan, kemajuan teknologi, dan kehidupan sosial ekonomi masyarakat yang harus tetap mampu meningkatkan pelayanan yang lebih bermutu dan terjangkau oleh masyarakat agar terwujud derajat kesehatan yang setinggi-tingginya. Dari pengertian tersebut, rumah sakit melakukan beberapa jenis pelayanan diantaranya pelayanan medik, pelayanan penunjang medik, pelayanan perawatan, pelayanan rehabilitasi, pencegahan dan peningkatan kesehatan, sebagai tempat pendidikan, pelatihan medik dan para medik, sebagai tempat penelitian, pengembangan ilmu dan teknologi bidang kesehatan. Selain dituntut mempu memberikan pelayanan dan pengobatan yang bermutu, Rumah Sakit juga dituntut harus melaksanakan dan mengembangkan program Kesehatan dan Keselamatan Kerja di Rumah Sakit (K3RS) seperti yang tercantum dalam buku Standar Pelayanan Rumah Sakit dan terdapat dalam instrumen akreditasi Rumah Sakit.

Bekerja di rumah sakit dapat menimbulkan risiko tertular penyakit dari pasien. Potensi bahaya di RS, selain penyakitpenyakit infeksi juga ada potensi bahayabahaya lain yang mempengaruhi situasi dan kondisi di RS, yaitu kecelakaan (peledakan, kebakaran, kecelakaan yang berhubungan dengan instalasi listrik, dan sumber-sumber cidera lainnya), radiasi, bahan-bahan kimia yang berbahaya, gas-gas anastesi, gangguan psikososial dan ergonomi.Semua potensi bahaya tersebut diatas, jelas mengancam jiwa dan kehidupan bagi para karyawan di RS, para pasien maupun para pengunjung yang ada di lingkungan RS (Teguh, 2008).

Risiko ini tidak hanya berpotensi bagi tenaga medis saja, namun juga terhadap tenaga non medis seperti petugas kebersihan. Karyawan rumah sakit terdiri dari tenaga medis dan tenaga non medis. Tenaga medis yaitu dokter, perawat, dan bidan sedangkan tenaga non medis yaitu petugas laundry, petugas kebersihan, petugas penyiapan makanan atau gizi, apoteker, Pemeriksa laboratorium, dan petugas radiologi (Wichaksana, 2002). Dilihat dari jenis pekerjaan yang ada di rumah sakit, dapat dikatakan tenaga medis merupakan karyawan yang rentan terkena penyakit akibat kerja, karena mereka selalu melakukan kontak dengan pasien yang sakit setiap hari.

Karyawan terkhusus perawat sebagai aset penting rumah sakit harus dijaga dan dibina agar selalu dalam kondisi yang sehat dan bebas dari pengaruh negatif yang disebabkan oleh bahaya di tempat kerja. Berdasarkan tempat kerja karyawan terbagi menjadi 4 zona risiko 
yaitu zona risiko rendah, zona risiko sedang, zona risiko tinggi dan zona risiko sangat tinggi. Zona risiko tinggi yaitu karyawan yang bekerja pada bagian ruangan operasi, ruang bedah mulut, ruang perawatan gigi, ruang rawat gawat darurat, ruang bersalin dan ruang patologi.

Perawat adalah tenaga kesehatan yang paling besar jumlahnya dan paling lama kontak dengan pasien, sehingga sangat berisiko dengan pekerjaannya, namun banyak perawat tidak menyadari terhadap risiko yang mengancam dirinya, melupakan keselamatan dan kesehatan kerja (K3). Data WHO (2004): Dari 35 juta pekerja kesehatan bahwa 3 juta terpajan patogen darah (2 juta terpajan virus HBV, 0.9 juta terpajan virus HBC dan 170.000 terpajan virus HIV/ AIDS). Probabilitas penularan HIV setelah luka tusuk jarum suntik yang terkontaminasi HIV 4: 1000. Risiko penularan HBV setelah luka tusuk jarum suntik yang terkontaminasi HBV 27-37: 100. Penelitian terhadap perawat perinatologi di RSUD Tugurejo Semarang, dalam satu tahun terakhir perawat mengalami kecelakaan kerja (tertusuk jarum) tertinggi 14 kali (Kurnia, 2013).

Beberapa komponen pelayanan kesehatan di rumah sakit, perawat adalah salah satu tenaga pelayanan kesehatan yang berinteraksi dengan pasien yang intensitasnya paling tinggi dibandingkan komponen lainnya. Perawat sebagai anggota inti tenaga kesehatan yang jumlahnya terbesar di rumah sakit (40-60\%) dan dimana pelayanan keperawatan yang diberikan merupakan bagian integral dari pelayanan kesehatan memiliki peran kunci dalam mewujudkan keselamatan dan kesehatan kerja (K3) di Rumah Sakit (Depkes, 2007).

Dalam Undang-Undang Nomor 36 Tahun 2009 tentang Kesehatan, Pasal 165 : pengelola tempat kerja wajib melakukan segala bentuk upaya kesehatan melalui upaya pencegahan, peningkatan, pengobatan, dan pemulihan bagi tenaga kerja. Berdasarkan pasal tersebut maka pengelola tempat kerja di Rumah Sakit mempunyai kewajiban untuk menyehatkan para tenaga kerjanya. Salah satunya adalah melalui upaya kesehatan kerja disamping keselamatan kerja. Rumah Sakit harus menjamin kesehatan dan keselamatan baik terhadap pasien, penyedia layanan atau pekerja maupun masyarakat sekitar dari berbagai potensi bahaya di Rumah Sakit. Oleh karena itu, Rumah Sakit dituntut untuk melaksanakan Upaya Kesehatan dan Keselamatan Kerja (K3) yang dilaksanakan secara terintegrasi dan menyeluruh sehingga risiko terjadinya Penyakit Akibat Kerja (PAK) dan Kecelakaan Akibat Kerja (KAK) di Rumah Sakit dapat dihindari. Penyakit akibat kerja di rumah sakit dapat menyerang semua tenaga kerja baik medis maupun non medis (Anies, 2005). Sehingga sasaran utama K3RS adalah tenaga medis, tenaga non medis, pasien, pengunjung / pengantar pasien, serta masyarakat sekitar Rumah Sakit. 
Penyakit Akibat Kerja adalah penyakit yang disebabkan oleh pekerjaan dan lingkungan kerja. Faktor risiko PAK antara lain: Golongan fisik, kimiawi, biologis atau psikososial di tempat kerja. Faktor tersebut di dalam lingkungan kerja merupakan penyebab yang pokok dan menentukan terjadinya penyakit akibat kerja. Faktor lain seperti kerentanan individual juga berperan dalam perkembangan penyakit di antara pekerja yang terpajan. Faktor risiko yang dapat menyebabkan terjadinya PAK adalah sebagai berikut:

1. Golongan fisik

a. Kebisingan dapat mengakibatkan gangguan pada pendengaran sampai dengan Non-induced hearing loss

b. Radiasi (sinar radio aktif) dapat mengakibatkan kelainan darah dan kulit

c. Suhu udara yang tinggi dapat mengakibatkan heat stroke, heat cramps, atau hyperpyrexia.

Sedangkan suhu udara yang rendah dapat mengakibatkan frostbite, trenchfoot atau hypothermia.

d. Tekanan udara yang tinggi dapat mengakibatkan caison disease

e. Pencahayaan yang tidak cukup dapat mengakibatkan kelahan mata. Pencahayaan yang tinggi dapat mengakibatkan timbulnya kecelakaan

2. Golongan kimia

a. Debu dapat mengakibatkan pneumokoniosis

b. Uap dapat mengakibatkan metal fume fever, dermatitis dan keracunan

c. Gas dapat mengakibatkan keracunan $\mathrm{CO}$ dan $\mathrm{H} 2 \mathrm{~S}$

d. Larutan dapat mengakibatkan dermatitis

e. Insektisida dapat mengakibatkan keracunan

3. Golongan infeksi

a. Anthrax

b. Brucell

c. HIV/AIDS

4. Golongan fisiologis

Dapat disebabkan oleh kesalahan kontruksi, mesin, sikap badan yang kurang baik, salah cara melakukan suatu pekerjaan yang dapat mengakibatkan kelelahan fisik bahkan lambat laun dapat menyebabkan perubahan fisik pada tubuh pekerja.

5. Golongan mental

Dapat disebabkan oleh hubungan kerja yang tidak baik atau keadaan pekerjaan yang monoton yang menyebabkan kebosanan. 
Menurut Peraturan Menteri Tenaga Kerja dan Transmigrasi Nomor

PER01/MEN/1981 dan Keputusan Presiden RI No 22/1993 terdapat 31 jenis penyakit akibat kerja yaitu sebagai berikut:

1. Pneumokoniosis yang disebabkan oleh debu mineral pembentukan jaringan parut (silikosis, antrakosilikosis, asbestosis) dan silikotuberkulosis yang silikosisnya merupakan faktor utama penyebab cacat atau kematian.

2. Penyakit paru dan saluran pernafasan (bronkopulmoner) yang disebabkan oleh debu logam keras.

3. Penyakit paru dan saluran pernafasan (bronkopulmoner) yang disebabkan oleh debu kapas, vlas, henep dan sisal (bissinosis).

4. Asma akibat kerja yang disebabkan oleh penyebab sensitisasi dan zat perangsang yang dikenal berada dalam proses pekerjaan.

5. Alveolitis allergika yang disebabkan oleh faktor dari luar sebagai akibat penghirupan debu organik

6. Penyakit yang disebabkan oleh berillium atau persenyawaannya yang beracun.

7. Penyakit yang disebabkan oleh kadmium atau persenyawaannya yang beracun.

8. Penyakit yang disebabkan oleh fosfor atau persenyawaannya yang beracun.

9. Penyakit yang disebabkan oleh krom atau persenyawaannya yang beracun.

10. Penyakit yang disebabkan oleh mangan atau persenyawaannya yang beracun.

11. Penyakit yang disebabkan oleh arsen atau persenyawaannya yang beracun.

12. Penyakit yang disebabkan oleh raksa atau persenyawaannya yang beracun.

13. Penyakit yang disebabkan oleh timbal atau persenyawaannya yang beracun.

14. Penyakit yang disebabkan oleh flour atau persenyawaannya yang beracun.

15. Penyakit yang disebabkan oleh karbon disulfida.

16. Penyakit yang disebabkan oleh derivat halogen dari persenyawaan hidrokarbon alifatik atau aromatik yang beracun.

17. Penyakit yang disebabkan oleh benzena atau homolognya yang beracun.

18. Penyakit yang disebabkan oleh derivat nitro dan amina dari benzena atau homolognya yang beracun.

19. Penyakit yang disebabkan oleh nitrogliserin atau ester asam nitrat lainnya.

20. Penyakit yang disebabkan oleh alkohol, glikol atau keton.

21. Penyakit yang disebabkan oleh gas atau uap penyebab asfiksia atau keracunan seperti karbon monoksida, hidrogen sianida, hidrogen sulfida atau derivatnya yang beracun, amoniak, seng, braso dan nikel. 
22. Kelainan pendengaran yang disebabkan oleh kebisingan.

23. Penyakit yang disebabkan oleh getaran mekanik (kelainan-kelainan otot, urat, tulang persendian, pembuluh darah tepi atau syaraf tepi).

24. Penyakit yang disebabkan oleh pekerjaan dalam udara yang bertekanan lebih.

25. Penyakit yang disebabkan oleh radiasi elektromagnetik dan radiasi yang mengion.

26. Penyakit kulit (dermatosis) yang disebabkan oleh penyebab fisik, kimiawi atau biologik.

27. Kanker kulit epitelioma primer yang disebabkan oleh ter, pic, bitumen, minyak mineral, antrasena, atau persenyawaan, produk atau residu dari zat tersebut.

28. Kanker paru atau mesotelioma yang disebabkan oleh asbes.

29. Penyakit infeksi yang disebabkan oleh virus, bakteri, atau parasit yang didapat dalam suatu pekerjaan yang memiliki resiko kontaminasi khusus.

30. Penyakit yang disebabkan oleh suhu tinggi atau rendah atau panas radiasi atau kelembaban udara tinggi.

31. Penyakit yang disebabkan oleh bahan kimia lainnya termasuk bahan obat.

\section{Penutup}

\section{Kesimpulan}

Penyakit Akibat Kerja adalah penyakit yang disebabkan oleh pekerjaan dan lingkungan kerja. Faktor risiko PAK antara lain: Golongan fisik, kimiawi, biologis atau psikososial di tempat kerja. Faktor tersebut di dalam lingkungan kerja merupakan penyebab yang pokok dan menentukan terjadinya penyakit akibat kerja. Faktor lain seperti kerentanan individual juga berperan dalam perkembangan penyakit di antara pekerja yang terpajan.

\section{Saran}

Perawat sebagai tenaga kesehatan yang paling lama kontak dengan pasien harus memahami risikonya dan menerapkan $\mathrm{k} 3$ dengan sebaik-baiknya agar tidak terjadi penyakibat akibat kerja (PAK) dan kecelakaan akibat kerja (KAK). Sebab pelayanan keperawatan memegang kunci dalam upaya penerapan $\mathrm{k} 3$.

\section{Daftar Pustaka}

Azizah, N., Setiawan., \& Gerry, S. (2018). Hubungan Antara Pengawasan, Prosedur KERJA Dan Kondisi Fisik Dengan Terjadinya Kecelakaan Kerja Pada Perawat Di Ruang Rawat Inap Rumah Sakit Permata Bunda Medan Tahun 2017. Jurnal JUMANTIK, 3(2), 125-134.

I, S. M. I., Joko, W., \& Erlisa, C. (2015). Kejadian Kecelakaan Kerja Perawat Berdasarkan Tindakan Tidak Aman. Jurnal Care, 3(2), 10-11.

Indragiri, S., \& Triesda, Y. (2018). Manajemen Risiko K3 Menggunakan Hazard Identification Risk Assessment And Risk Control (HIRARC). Jurnal Kesehatan, 9(1), 39-52. 
Mantiri, E. Z. R. A., Odi, R. P., \& Sylvia, M. (2020). Faktor Psikologi Dan Perilaku Dengan Penerapan Manajemen Keselamatan Dan Kesehatan Kerja Rumah Sakit. Indonesian Journal of Public Health and Community Medicine, 1(3), 20-25.

Octavia, W. R., Diana, N., \& Ernita, S. (2018). Penerapan Pelayanan Kesehatan Dan Keselamatan Kerja Pada Perawat IGD Rumah Sakit Umum DR. Wahidin Husodo Mojokerto Tahun 2017. Gema Kesehatan Lingkungan, 16(1), 101-107.

Putri, S., Santoso., \& Endang, P. R. (2018). Pelaksanaan Keselamatan Dan Kesehatan Kerja Terhadap Kejadian Kecelakaan Kerja Perawat Rumah Sakit. Jurnal Endurance, 3(2), 271-273.

Salawati, L. (2015). Penyakit Akibat Kerja Dan Pencegahan. Jurnal Kedokteran Syiah Kuala, 15(2), 91-94.

Salmawati, L., Muh, R., \& Muh, R. N. (2019). Faktor Yang Berhubungan Dengan Kejadian Kecelakaan Kerja Pada Perawat Di Ruang IGD RSU Anutapura Kota Palu. Jurnal Kesehatan Masyarakat, 10(2), 106-110.

Sandewa, S., \& Ardian, A. (2014). Hubungan Perilaku Dengan Resiko Kecelakaan Kerja Pada Perawat Di Ruang Rawat Inap RSUD Labuang Baji Makassar. Jurnal IImiah Kesehatan Diagnosis, 5(4), 500-501.

Simamora, R. H. (2017). A strengthening of role of health cadres in BTA-Positive Tuberculosis (TB) case invention through education with module development and video approaches in Medan Padang bulan Comunity Health Center, North Sumatera Indonesia. International Journal of Applied Engineering Research, 12(20), 10026-10035.

Simamora, R. H., \& Saragih, E. (2019). Penyuluhan kesehatan terhadap masyarakat: Perawatan penderita asam urat dengan media audiovisual. JPPM (Jurnal Pendidikan dan Pemberdayaan Masyarakat), 6(1), 24-31.

Yuantar, C. M., \& Hafizhatun, N. (2018). Analisis Risiko Keselamatan dan Kesehatan Kerja Pada Petugas Kebersihan di Rumah Sakit. Health Journal, 5(3), 107-109.

Yunita, A. R., Ayun, S., \& Eka, Y. F. (2016). Analisis Faktor-Faktor Kebijakan Dalam Implementasi Program Keselamatan Dan Kesehatan Kerja Rumah Sakit (K3RS) Di Instalasi Gawat Darurat Rumah Sakit Umum Daerah Kota Semarang. Jurnal Kesehatan Masyarakat, 4(2), 1-8. 